\title{
DETERMINAN TABUNGAN MUDHARABAH DI INDONESIA
}

\author{
Roikhan Moch. Aziz dan Siti Suharyanti \\ UIN Syarif Hidayatullah Jakarta \\ roikhan@uinjkt.ac.id
}

\begin{abstract}
.
The objective of this research to determine how the influence of macro variables were Profit Sharing Ratio (equivalent rate), Inflation, GDP, and SWBI against Mudharabah Savings at Islamic Banking in Indonesia. The data used in this research were data time series by using multiple regressions and analysis by Ordinary Least Squares. The results showed that simultaneously independent variables (Profit Sharing ratio, Inflation, GDP, and SWBI have significant influence the dependent variable (MudharabaH Savings) with probability 0.000000. End that partially independent variables (Inflation with probability $0.0013, G D P$ with probability 0.0000 , and SWBI with probability 0.0000 have positively influence and significantly to dependent variable (Mudharabah Savings) in the Islamic Banking of Indonesia. While between the variable independent (Profit Sharing ratio) to dependent variable (Mudharabah Savings) have not significantly with probability 0.2040, in the Islamic Banking of Indonesia.
\end{abstract}

Keywords: Profit Sharing Ratio; Inflation; GDP; SWBI; Mudharabah Savings; OLS.

\begin{abstract}
Abstrak.
Tujuan dari penelitian ini untuk mengetahui bagaimana pengaruh variabel makro yaitu rasio profit sharing, Inflasi, PDB, dan SWBI terhadap Tabungan Mudharabah di Perbankan Syariah Indonesia. Data yang digunakan dalam penelitian ini adalah data time series dengan menggunakan regresi berganda dan analisis oleh Kuadrat Terkecil Biasa. Hasil penelitian menunjukkan bahwa variabel secara bersamaan independen (rasio profit sharing, Inflasi, PDB, dan SWBI berpengaruh signifikan terhadap variabel dependen (Tabungan Mudharabah) dengan probabilitas 0,000000. Variabel independen (Inflasi dengan probabilitas 0,0013, PDB dengan probabilitas 0,0000, dan SWBI dengan probabilitas 0,0000 berpengaruh positif dan signifikan terhadap variabel dependen (Tabungan Mudharabah) di Perbankan Syariah Indonesia. Sementara antara variabel independen (rasio profit sharing) terhadap variabel dependen (Tabungan Mudharabah) tidak signifikan dengan probabilitas 0,2040, di Perbankan Syariah Indonesia.
\end{abstract}

Kata Kunci: Rasio Profit Sharing; Inflasi; PDB; SWBI; Tabungan Mudharabah; OLS.

Diterima: 20 Juli 2013; Direvisi: 17 Agustus 2013; Disetujui: 3 September 2013 


\section{PENDAHULUAN}

Faktor pendukung kebijakan moneter adalah dengan adanya lembaga perbankan. Lembaga perbankan adalah salah satu perantara antara unit-unit ekonomi yang membutuhkan dana dengan unit-unit yang memiliki dana. Lembaga perbankan dibagi menjadi dua yaitu perbankan Konvensional dan perbankan Syariah (Pohan, 2008). Bank Konvensional adalah bank yang dalam sistem operasionalnya menerapkan sistem bunga, karena metode bunga sudah ada terlebih dahulu dan menjadi kebiasaan yang telah secara meluas dibanding dengan metode bagi hasil. Sedangkan Bank Syariah adalah lembaga keuangan yang usaha pokoknya memberikan kredit, pembiayaan dan jasa-jasa lainnya dalam lalu lintas pembayaran serta peredaraan uang yang pengoperasiannya disesuaikan dengan prinsip-prinsip Syariah (UU No. 10/1998) (Sudarsono, 2003).

Bank Muamalat Indonesia (BMI) menjadi awal berdirinya Bank Islam (Bank Syariah). Tetapi banyak perbankan yang meragukan adanya eksistensi Bank Syariah. Tetapi Bank Syariah mencoba memberi pernyataan dalam menjawab keraguan tersebut yang sering timbul dari semua pihak baik masyarakat maupun pemerintah. Pada awal tahun 1997, dimana Indonesia mengalami krisis ekonomi yang sangat memprihatinkan dan menjadikan pertumbuhan ekonomi Indonesia menjadi terpuruk. Sehingga muncul Bank Syariah yang menjadi salah satu penggerak dalam mengurangi keterpurukan tersebut.

Perkembangan jaringan kantor Perbankan Syariah dari tahun ke tahun mengalami peningkatan. Hal ini dibuktikan bahwa jumlah BUS dan UUS pada tahun 2002127 unit, 2003253 unit, 2004355 unit, 2005550 unit, 2006637 unit, 2007783 unit, 20081024 unit, dan 20091223 unit Perkembangan Perbankan Syariah di Indonesia tidak akan terlepas dari peranan kebijakan Bank Indonesia dalam mengendalikan moneter berdasarkan prinsip Syariah yaitu dengan adanya Operasi Moneter Syariah (OMS) adalah pelaksanaan kebijakan moneter oleh Bank Indonesia dalam rangka mengendalikan kebijakan moneter melalui kegiatan Operasi Pasar Terbuka (OPT) dan mengeluarkan standing fasilitas berdasarkan prinsip Syariah seperti SWBI dan sekarang disebut SBIS. OPT adalah kebijakan untuk mengatasi kelebihan liqiuditas.

Di Bank Syariah terdapat pengimpunan Dana Pihak Ketiga (DPK) terdiri dari giro, tabungan, dan deposito. DPK sebagian didominasi oleh besarnya tabungan 
mudharabah yang saat ini telah mencapai 14 triliun rupiah pada bulan April tahun 2010. Dalam penghimpunan DPK tidak terlepas dari faktor-faktor seperti Nisbah Bagi Hasil, Inflasi, Pendapatan Nasional (PDB) dan SWBI. Prinsip bagi hasil (Profit Sharing) merupakan karakteristik umum dari operasional Perbankan Syariah secara keseluruhan. Secara Syariah, prinsip ini berdasarkan pada kaidah al mudharabah dengan arti bank sebagai mitra, dan penabung sebagai pemilik dana dengan kesepakatan keuntungan tertentu (Ghafur W, 2003). Inflasi sebenarnya mencerminkan kestabilan nilai sebuah mata uang. Stabilitas tersebut tercermin dari stabilitas tingkat harga yang kemudian berpengaruh terhadap realisasi pencapaian tujuan pembangunan ekonomi suatu negara, seperti pemenuhan kebutuhan dasar, pemerataan distribusi pendapatan dan kekayaan, perluasan kesempatan kerja, dan stabilitas ekonomi. Selain tingkat inflasi, tabungan juga dipengaruhi oleh perkembangan PDB. Tingkat kesejahteraan masyarakat diukur dari pendapatan nasionalnya yaitu PDB/GDP yang dilihat dari harga konstan.

Berdasarkan latar belakang masalah tersebut, dapat diketahui bahwa salah satu perbedaan utama antara Perbankan Konvensional dengan Perbankan Syariah adalah tingkat suku bunga (Perbankan Konvensional) dan tingkat bagi hasil (Perbankan Syariah). Bisa dikatakan bahwa sistem bagi hasil dalam sistem Perbankan Syariah merupakan pengganti suku bunga di dalam sistem Perbankan Konvensional. Tujuan yang ingin dicapai dari penelitian ini adalah mengetahui pengaruh antara Nisbah Bagi Hasil, Inflasi, Pendapatan Nasional/PDB, dan SWBI terhadap Tabungan Mudharabah.

\section{Tabungan Mudharabah}

Tabungan (saving deposit) adalah simpanan yang penarikannya harus dapat dilakukan menurut syariat tertentu yang disepakati, tetapi tidak dapat ditarik dengan cek, bilyet dan lain-lain. tabungan ini hanya bisa ditarik dengan cara nasabah membawa buku rekening tabungan, slip pembayaran atau lewat ATM. Beberapa definisi Tabungan Mudharabah sebagai berikut:

a. Tabungan Mudharabah adalah tabungan yang berdasarkan prinsip mudharabah muthlaqah. Dalam hal ini Bank Syariah mengelola dana yang diinvestasikan oleh penabung secara produktif, menguntungkan dan memenuhi prinsip-prinsip syariah Islam. Hasil keuntungannya akan dibagikan kepada penabung dan bank sesuai perbandingan bagi hasil atau nisbah yang disepakati bersama. Apabila tabungan 
hanya ditimbun tanpa diinvestasikan, maka bagaikan harta yang tidak berguna karena Islam tidak menyukai adanya tindakan penimbunan harta yang sia-sia/tidak diinvestasikan (Karim, 2004).

b. Menurut Muhammad tabungan mudharabah adalah dana yang disimpan akan dikelola oleh pihak bank dengan tujuan untuk memperoleh keuntungan,dan keuntungan tersebut akan diberikan kepada nasabah berdasarkan kesepakatan bersama. Tabungan tersebut dapat diambil setiap saat oleh penabung sesuai dengan perjanjian yang disepakati, namun tidak di perkenankan mengalami saldo negatif (Sutedi, 2009).

Standarisasi Akad Tabungan Mudharabah adalah sebagai berikut: (Ascarya, 2007):

a. Pada setiap penerimaan nasabah baru, diwajibkan untuk menerangkan esensi tabungan mudharabah serta kondisi penerapannya seperti bentuk investasi nasabah ke bank, definisi dan terminologi, keikutsertaan dalam skema penjaminan, profit sharing atau profit revenue, term and conditions dan tata cara perhitungan bagi hasil.

b. Bank wajib meminta nasabah untuk mengisi formulir jika tidak terjadi akad yang disertakan.

c. Nasabah wajib menandatangani formulir permohonan tersebut sebagai bukti adanya kehendak dari pihak pemilik dana untik menyerahkan dananya kepada bank pengelola.

d. Apabila bank setuju, bank wajib menandatangani formulir tersebut sebagai bukti adanya kesanggupan pihak bank sebagai pihak yang mengelola dana.

e. Nasabah wajib menyetorkan dana sebesar nominal yang ditulis dalam formulir permohonan sebagai bukti investasi tunai bukan utang serta menegaskan jumlah investasi yang sesuai dengan yang disepakati.

f. Apabila terjadi adanya perubahan nisbah bagi hasil untuk periode mendatang. Maka bank wajib mengumumkan sebelum nisbah bagi hasil tersebut diberlakukan dalam jangka waktu tertentu sesuai kebijakan bank.

g. Bank wajib mengumumkan pendapatan akan bagi hasil (basis angka, share base) yang menjadi acuan pembagian hasil pada setiap dilakukannya proses pembagian hasil oleh bank untuk periode tertentu.

h. Tabungan hanya dapat ditutup setelah periode investasi berakhir. 


\section{Nisbah Bagi Hasil}

Bagi hasil menurut terminologi asing (Inggris) dikenal dengan profit sharing. Profit sharing dalam kamus ekonomi diartikan dengan pembagian laba. Secara definitif profit sharing diartikan:"distribusi beberapa bagian dari laba pada para pegawai dari suatu perusahaan". Hal itu dapat berbentuk suatu bonus uang tunai tahunan yang didasarkan pada laba yang diperoleh pada tahun-tahun sebelumnya, atau dapat berbentuk pembayaran mingguan/bulanan (Muhamad, 2004).

Metode bagi hasil terdiri dari dua sistem: (Antonio, 2002)

a. Bagi untung (Profit Sharing) adalah bagi hasil yang dihitung dari pendapatan setelah dikurangi biaya pengelolaan dana. Dihitung dari pendapatan netto setelah dikurangi biaya bank, maka kemungkinan yang akan terjadi adalah bagi hasil yang akan diterima oleh para shahibul maal (pemilik dana) akan semakin kecil, tentunya akan mempunyai dampak yang cukup signifikan apabila ternyata secara umum tingkat suku bunga pasar lebih tinggi.

b. Bagi hasil (Revenue Sharing) adalah bagi hasil yang dihitung dari total pendapatan pengelolaan dana berdasarkan bagi hasil yang akan didistribusikan dihitung dari total pendapatan bank sebelum dikurangi dengan biaya bank, maka kemungkinan yang akan terjadi adalah tingkat bagi hasil yang diterima oleh pemilik dana akan lebih besar dibandingkan dengan tingkat suku bunga pasar yang berlaku.

Hal-hal yang berkaitan dengan nisbah bagi hasil yaitu: (Karim, 2004)

a. Prosentase, Nisbah keuntungan harus didasarkan dalam bentuk prosentase antara kedua belah pihak, bukan dinyatakan dalam nilai nominal rupiah tertentu. Nisbah keuntungan seperti 50:50, 70:30, 60:40, atau 99:1.

b. Bagi Untung dan Bagi Rugi, karakteristik akad mudharabah yang tergolong ke dalam kontrak investasi (natural uncertainty contracts). Dalam kontrak ini, return dan timing cash flow tergantung kepada kinerja sektor riilnya. Bila laba bisnisnya besar, kedua belah pihak mendapat bagian yang besar pula. Bila laba bisnisnya keci, maka akan mendapat bagian yang kecil juga.

c. Jaminan, ketentuan pembagian kerugian, bila kerugian yang terjadi hanya murni diakibatkan oleh risiko bisnis (business risk), bukan karena risiko karakter buruk mudharib (character risk). Bila kerugian terjadi karena 
karakter buruk, misalnya karena mudharib lalai dan atau melanggar persyaratanpersyaratan kontrak mudharabah, maka shahib al-maal tidak perlu menanggung kerugian.

d. Menentukan Besarnya Nisbah ditentukan berdasarkan kesepakatan masingmasing pihak yang berkontrak. Jadi, angka besaran nisbah sebagai hasil tawar-menawar antara shahib al-maal dengan mudharib, angka nisbah ini bervariasi, bisa 50:50, 60:40, 70:30, 80:20, bahkan 99:1.

\section{Inflasi}

Inflasi adalah suatu keadaan dimana terjadi kenaikkan harga secara tajam yang berlangsung secara terus menerus dalam jangka waktu yang cukup lama sebagai akibat dari ketidakseimbangan arus barang dan jasa seiring dengan nilai mata uang yang turun secara tajam. Kenaikan harga dari satu atau dua barang saja tidak dapat disebut inflasi kecuali bila kenaikan itu meluas (atau mengakibatkan kenaikan harga) pada barang lainnya, kebalikan dari inflasi disebut deflasi. (Khalwaty, 2000). Cara menghitung laju inflasi adalah perubahan presentase dalam indeks harga dari jangka waktu yang sebelumnya. Rumus adalah sebagai berikut: (Mankiw, 2002)

Laju Inflasi $=\frac{I H K_{2}-I H K_{1}}{I H K_{1}} \times 100$

Penyebab terjadinya Inflasi Ada beberapa penyebab terjadinya inflasi yaitu terdiri dari: (Sukirno, 2004)

a. Inflasi tarikan permintaan (demand-full inflation) merupakan inflasi yang diakibatkan oleh perubahan-perubahan yang terjadi pada sisi Permintaan Agregat (AD $\uparrow)$ dari barang dan jasa dalam perekonomian. Mengakibatkan ekonomi menghadapi pengangguran yang tinggi pada kesempatan penuh. Perekonomian mengalami tidak mampu menaikkan produksi maka agregat permintaan naik dan harga juga naik. Selain itu adalah tingkat ekspor tinggi menyebabkan pendapatan naik terus menerus, konsumsi dan belanja negara juga naik. Sehingga berakibat perusahaan investasi semakin meningkat pada kesempatan kerja penuh.

b. Inflasi desakan biaya (Cost Push Inflation) merupakan jenis inflasi yang terjadi karena perubahan-perubahan pada sisi Penawaran Agregat (AS) dari barang dan jasa pada perekonomian. Tingkat kesempatan kerja penuh pada saat perusahaan 
beroperasi pada kapasitas maksimal dan pengangguran tenaga kerja rendah. Sehingga menyebabkan peningkatan biaya produksi. Biaya produksi naik mengakibatkan harga naik karena harga naik maka daya beli masyarakat menjadi kurang.

c. Impoerted Inflation dan Domestic Inflation merupakan bentuk inflasi yang disebabkan karena kenaikan harga minyak 3x lipat tahun 1973 yang dilakukan untuk negara Timur Tengah seperti minyak Petroleum merupakan sumber enegri terpenting dalam industri negara barat.

Macam-macam ukuran inflasi adalah sebagi berikut: (Sukirno, 2004):

a. Inflasi ringan adalah tingkat inflasi yang berada dibawah $10 \%$ dalam setahun.

b. Inflasi sedang adalah tingkat inflasi yang berada diantara $10-30 \%$ dalam setahun.

c. Inflasi berat adalah tingkat inflasi yang berkisar antara 30\%-100\% dalam setahun.

d. Inflasi tinggi (hyperinflation) adalah tingkat inflasi yang berkisar lebih dari $100 \%$ dalam setahun.

\section{Pendapatan Nasional/PDB}

Pendapatan Nasional adalah jumlah barang dan jasa yang dihasilkan suatu negara pada periode tertentu biasanya satu tahun. Istilah lain pendapatan nasional antara lain: produk domestik bruto (Gross Domestic Product/GDP atau Product Domestic Bruto/PDB), produk nasional bruto (Gross National Product/GNP ) serta produk nasional netto (Net National Product/NNP) ( Huda dkk., 2007).

\section{Sertifikat Wadiah Bank Indonesia}

Sertifikat Wadi'ah Bank Indonesia (SWBI) adalah sertifikat yang diterbitkan Bank Indonesia sebagai bukti penitipan dana jangka pendek dengan prinsip wadi'ah. SWBI merupakan piranti moneter yang sesuai prinsip pada Bank Syariah yang diciptakan dalam rangka pelaksanaan pengendalian moneter. Bank Indonesia menerbitkan instrumen moneter berdasarkan prinsip Syariah yang dinamakan Sertifikat Wadi'ah Bank Indonesia (SWBI) dan dapat dimanfaatkan oleh Bank Syariah untuk mengatasi bila terjadi kelebihan pada tingkat liquiditas (Arifin, 2006). 
Dewan Syariah Nasional (DSN) telah menerbitkan Fatwa No. 36/DSN-MUI/X/2002 tentang Sertifikat Wadi'ah Bank Indonesia, yang mengatur hal-hal sebagai berikut: (Sutedi, 2009).

a. Bank Indonesia selaku bank sental boleh menerbitkan instrumen moneter berdasarkan prinsip Syariah yang dinamakan SWBI.

b. Akad yang digunakan untuk SWBI adalah akad wadi'ah sebagaimana yang diatur Fatwa DSN No.02/DSN-MUI/IV/2000 tentang tabungan.

SWBI tidak boleh ada imbalan yang disyaratkan, kecuali dalam bentuk pemberian (athaya) yang bersifat sukarela dari pihak Bank Indonesia. SWBI boleh diperjualbelikan. Bank Indonesia dapat memberikan bonus atas titipan dana yang di perhitungkan jika pada saat jatuh tempo. Jumlah dana yang dapat dititipkan ke Bank Indonesia sekurang-kurangnya $\mathrm{Rp} 500.000 .00,00$. Pada titipan dana tersebut hanya dapat dilakukan dalam kelipatan $\mathrm{Rp} 50.000 .000,00$.

\section{METODE}

Model regresi linier berganda yang diperoleh adalah sebagai berikut: (Widarjono, 2007) Sedangkan model ekonometrika ditulis:

$\mathrm{TM}=\alpha+\beta 1 \mathrm{NBH}+\beta 2 \mathrm{INF}+\beta 3 \mathrm{PDB}+\beta 4 \mathrm{SWBI}+\mathrm{e}$ . .1

Apabila di transformasikan dalam persamaan regresi bentuk logaritma, maka menjadi:



Dimana :

$\mathrm{TM}=$ Tabungan Mudharabah

$\mathrm{NBH}=$ Nisbah Bagi Hasil

INF = Inflasi

PDB = Pendapatan Nasional

SWBI = Sertifikat Wadi'ah Bank Indonesia

$\alpha=$ Konstanta

$\beta 1, \beta 2, \beta 3, \& \beta 4=$ Koefisien regresi dari masing-masing variabel yang mempengaruhi pendapatan.

$e=$ Variabel diluar model tetapi tidak ikut berpengaruh terhadap varibel terikat . 


\section{Uji Normalitas}

Uji signifikasi pengaruh variabel independen terhadap variabel dependen melalui uji t hanya akan valid jika residual yang didapatkan mempuntai distribusi normal. Model regresi yang baik adalah distribusi data normal atau mendekati normal. Uji Normalitas menjadi sangat populer dan tercakup dibeberapa komputer statistik (Gujarati, 2007). Uji normalitas residual metode OLS secara formal dapat dideteksi dari metode yang dikembangkan oleh Jarque-Bera (J-B). Deteksi dengan melihat Jarque-Bera test yang merupakan asimtotis (sampel besar dan didasarkan atas residual OLS) yaitu dengan melihat $\mathrm{J}-\mathrm{B}>\alpha 5 \%$ maka data berdistribusi normal.

\section{Uji Multikolinieritas}

Uji asumsi tentang multikolinieritas ini dimaksudkan untuk membuktikan atau menguji ada tidaknya hubungan yang linear antara variabel bebas (independen) satu dengan variabel bebas (independent) lainnya. Jika terjadi korelasi, maka akan terdapat problem Multikolenieritas. Cara mendeteksi adanya multikolinearitas dengan metode Deteksi Klien yaitu dengan membandingkan $\mathrm{R}^{2}$ hasil regresi Auxiliary (regresi antar variabel independen) dengan $R^{2}$ regresi aslinya. $R^{2}$ regresi Auxiliary < regresi aslinya maka data tidak ada multikolinearitas (Gujarati, 2007).

\section{Uji Heteroskedastisitas}

Uji Heteroskedastisitas bertujuan untuk menguji apakah dalam sebuah model regresi, terjadi ketidaksamaan varians dari residual dari antara satu pengamatan ke pengamatan lain. Jika varians dari residual dari satu pengamatan ke pengamatan yang lain tetap, maka disebut Homoskedastisitas. Jika varians berbeda atau tidak konstan, sehingga seakan-akan terdapat kelompok data yang memiliki besaran error maka terjadi heteroskedastisitas. Model regresi yang baik adalah tidak terjadi Heteroskedastisitas (Gujarati, 2007) Pendeteksian heteroskedastisitas dalam model ini dengan menggunakan: Uji White Heteroskedastisity yaitu dengan melakukan estimasi fungsi regresi terlebih dahulu dengan mengspesifikasikan variabel bebas dan variabel tidak bebas, jika Chi_square > a $5 \%$ maka data tidak ada heteroskedastisitas (Gujarati, 2007). 


\section{Uji Autokorelasi}

Uji Autokorelasi bertujuan untuk menguji apakah dalam sebuah model regresi linier ada korelasi antara kesalahan penggangu pada periode $t$ dengan kesalahan pada periode t-1 (sebelumnya). Jika terjadi korelasi, maka dinamakan ada problem Autokorelasi. Tentu saja model regresi yang baik adalah regresi yang bebas dari autokorelasi (Gujarati, 2007:112).

Deteksi adanya autokorelasi dapat menggunakan Besaran DURBIN-WATSON (D-W). Secara umum peniliaian besaran D-W dapat diambil patokan: (Gujarati, 2007:116).

1. Angka D-W di bawah -2 berarti ada autokorelasi positif.

2. Angka D-W di antara -2 sampai +2 , berarti tidak ada autokorelasi.

3. Angka $D-W$ di atas +2 berarti ada autokorelasi negatif.

\section{Uji Statistik}

Adapun pengujian hipotesis penelitiannya adalah sebagai berikut : Pengaruh variabel Inflasi terhadap DPK

Ho : $B 1=0$ (Variabel Nisbah Bagi Hasil, Inflasi, PDB, dan SWBI tidak berpengaruh terhadap Tabungan Mudharabah)

$\mathrm{H} 1$ : $\mathrm{B1}=\mathrm{O}$ (Variabel Nisbah Bagi Hasil, Inflasi, PDB, dan SWBI berpengaruh terhadap Tabungan Mudharabah

a. Uji Parsial (uji-t) digunakan untuk mendeteksi seberapa baik variabel bebas (Independent variabel) dapat menjelaskan variabel tidak bebas (Dependent variabel) secara individu dengan menggunakan $\alpha 5 \%$.

b. Uji Fisher (uji-f) Uji Fisher (uji F) digunakan untuk mengetahui apakah variabel bebas (Independent variabel) secara bersama-sama berpengaruh terhadap variabel tidak bebas (Dependent variabel) dengan menggunakan $\alpha 5 \%$.

\section{Koefisien Determinasi}

Koefisien determinan $\left(R^{2}\right)$ digunakan untuk mengukur sebaik mana variabel terikat dijelaskan oleh total variabel bebas. Ukuranya adalah semakin tinggi $R^{2}$ maka garis regresi sampel semakin baik juga. $R^{2}$ mengartikan apakah variabel bebas yang terdapat dalam model mampu menjelaskan perubahan dari variabel tidak bebas. Jika $R^{2}$ mendekati satu maka variabel 
independent mampu menjelaskan perubahan variabel dependent, tetapi jika $R^{2}$ mendekati 0 , maka variabel independent tidak mampu menjelaskan variabel dependent.

\section{HASIL DAN PEMBAHASAN}

Hasil pengolahan data menggunakan regresi linier berganda dengan metode OLS (Ordinary Least Squeres) untuk model persamaan LTM = $\mathrm{f}(\mathrm{LNBH}, \mathrm{LINF}, \mathrm{LPDB}, \mathrm{LSWBI})$.

\section{Nisbah Bagi Hasil (NBH)}

Probability $\beta_{2}=0.2040 \geq \alpha 5 \%=$ tidak Signifikan $\left(\mathrm{H}_{0}\right.$ diterima, $\mathrm{H}_{1}$ ditolak), artinya tidak terdapat pengaruh antara Nisbah Bagi Hasil terhadap Tabungan Mudharabah. Karena tidak signifikan maka Nisbah Bagi Hasil tidak berpengaruh terhadap Tabungan Mudharabah. Hal ini disebabkan dikarenakan naik turunnya equivalent rate yang diberikan oleh Bank kepada nasabah tidak berpengaruh terhadap kehendak masyakat untuk menabung. Hal ini terbukti pada jangka pendek equivelent rate relatif lebih stabil tetapi jangka panjang relatif mengalami fluktulatif. sehingga hal tersebut menjadi bukti bahwa kehendak masyarakat untuk menabung di Perbankan Syariah bukan dipengaruhi oleh motif untuk mendapatkan return berupa bagi hasil. Melainkan masyarakat ingin menabung karena sistem bank yang lebih Islami yaitu bank yang sistem operasionalnya terhindar dari riba, gharar, dan maysir.

Apabila mengacu kepada hasil penelitian terdahulu, yang dilakukan oleh Ghafur (2003), "Pengaruh Tingkat Bagi Hasil terhadap Simpanan Mudharabah pada periode tahun 1993 - 2001 di BMI (Bank Muamalat Indonesia)". Dengan hasil penelitian bahwa Tingkat Nisbah Bagi Hasil berpengaruh terhadap Simpanan Mudharabah. Hal ini dikarenakan kecenderungan masyarakat untuk menabung di Perbankan Syariah adalah bukan karena motif untuk mendapat keuntungan (bagi hasil) tetapi dikarenakan sistemnya yang lebih Islami, maka penelitian tersebut mendukung kesimpulan pada regresi ini (Ghafur, 2003).

\section{Inflasi (INF)}

Probability $\beta_{3}=0.0041 \leq \alpha 5 \%$ = Signifikan $\left(H_{0}\right.$ ditolak, $H_{1}$ ditolak $)$, artinya terdapat pengaruh antara inflasi terhadap Tabungan Mudharabah. Variabel tingkat Inflasi mempunyai pengaruh positif dan signifikan dengan Tabungan 
mudharabah dengan koefisien 0.088059, artinya setiap kenaikan Inflasi sebesar satu persen, maka akan meningkatkan tabungan mudharabah sebesar 0.088059 persen.

Hal ini dikarenakan selama Inflasi di Indonesia masih tergolong Inflasi ringan atau sedang maka itu berdampak positif terhadap perekonomian seperti meningkatnya semangat untuk menabung, meningkatnya investasi dalam perekonomian. Tetapi apabila Inflasi tergolong hyperinflasi maka justru akan berdampak negatif terhadap perekonomian seperti menurunya semangat menabung, menurunnya investasi dalam perekonomian. Dan karena Tingkat Inflasi naik menyebabkan harga barang-barang suatu negara mengalami kenaikan secara terus menerus sebagai masalah bagi masyarakat. Hal ini terjadi kemungkinan dengan kenaikan inflasi berarti harga barang-barang mahal misalnya bahan makanan, pendidikan, perumahan, dan lain-lain, sehingga banyak masyarakat yang tidak mau membelanjakan uangnya dan mereka lebih suka menyimpan uangnya di bank (Aldrin dkk., 2008).

\section{Pendapatan Nasional/PDB}

Probability $\beta_{2}=0.0000 \leq \alpha 5 \%=$ Signifikan $\left(H_{0}\right.$ ditolak, $H_{1}$ ditolak), artinya terdapat pengaruh antara PDB terhadap Tabungan Mudharabah. Variabel tingkat Produk Domestik Bruto (PDB) mempunyai pengaruh positif dan signifikan dengan Tabungan Mudharabah dengan koefisien 5.358342, dimana setiap kenikan PDB sebesar satu persen akan meningkatkan Tabungan Mudharabah sebesar 5.358342 persen. Hal ini dikarenakan Pendapatan nasional/PDB berpengaruh terhadap tabungan disebabkan karena kuatnya kinerja investasi pada sektor riil sehingga mengakibatkan peningkatan PDB.

Dengan dorongan permintaan baik yang berasal dari dalam maupun luar negeri, sektor industri pengolahan, sektor perdagangan dan sektor pengangkutan menjadi motor pertumbuhan dengan sumbangan terhadap pertumbuhan PDB. Ketika pertumbuhan ekonomi suatu negara mengalami peningkatan maka hal tersebut berdampak pada kenaikan pendapatan nasional yang pada akhirnya mempengaruhi masyarakat dalam mengambil keputusan untuk pengeluaran konsumsi dan tabungan. Hal ini sesuai dengan teori yang dikemukakan oleh Keynes bahwa tingkat Pendapatan akan mempengaruhi tingkat Tabungan dengan fungsi Tabungan $S=Y-C$ atau $S=I, S=$ Tabungan, $\mathrm{Y}=$ Pendapatan, $\mathrm{C}=$ Konsumsi penawaran dana pinjaman tergantung pada 
Pendapatan dan kebijakan fiskal (kenaikan konsumsi dan penurunan pajak) sedangkan permintaan terhadap dana pinjaman tergantung pada tingkat bunga (Mankiw, 2003:264).

\section{SWBI}

Probability $\beta_{4}=0.0000 \leq$ dari $\alpha 5 \%$ = Signifikan $\left(H_{0}\right.$ ditolak, $H_{1}$ diterima $)$, artinya terdapat pengaruh Sertifikat Wadi'ah Bank Indonesia terhadap Tabungan Mudharabah. Variabel tingkat SWBI mempunyai pengaruh positif dan signifikan dengan Tabungan Mudharabah dengan koefisien 0.097649, dimana setiap kenaikan SWBI sebesar satu persen akan meningkatkan tabungan mudharabah sebesar nilai 0.097649 persen. Hal ini disebabkan semakin posisi outstanding SWBI naik yang akan mengakibatkan peningkatan pada bonus SWBI. Karena Bonus SWBI naik maka Bank Syariah akan memberi equivalen rate nisbah lebih tinggi untuk meningkatkan tabungan masyarakat. Sehingga apabila Bank Syariah memberi equivalen rate nisbah yang tinggi maka masyarakat akan cenderung menabung di Perbankan Syariah (Emilinshah dkk., 2005:142).

\section{SIMPULAN}

Secara bersama-sama (simultan) Nisbah Bagi Hasil, Inflasi, Pendapatan Nasional/PDB, dan Sertifikat Wadi'ah Bank Indonesia mempunyai pengaruh signifikan terhadap Tabungan Mudharabah dengan probability F-statistk Tabungan Mudharabah $=0.00000$ atau lebih kecil dari $\alpha 5 \%$.

Nisbah Bagi hasil mempunyai pengaruh negatif dan tidak signifikan terhadap Tabungan Mudharabah. Hal ini berarti kehendak masyarakat untuk menabung di Perbankan Syariah bukan dipengaruhi oleh motif untuk mendapatkan keuntungan (bagi hasil) tetapi disebabkan oleh faktor lain yang tidak dapat dikemukakan disini.

Inflasi mempunyai pengaruh positif dan signifikan terhadap Tabungan Mudharabah. Itu artinya ketika inflasi naik maka Tabungan Mudharabah juga akan naik, dikarenakan pada saat terjadi inflasi harga-harga naik secara terus menerus dan berakibat daya beli masyarakat menjadi turun. Turunnya daya beli masyarakat mengakibatkan masyarakat lebih memilih menyimpan kekayaannya dalam bentuk tabungan maupun deposito di Bank. 
Pendapatan Nasional (PDB) mempunyai pengaruh yang positif dan signifikan terhadap Tabungan Mudharabah. Ini artinya ketika pendapatan yang dihasilkan oleh masyarakat pada suatu negara mengalami peningkatan, maka Tabungan Mudharabah juga mengalami peningkatan, karena tidak semua pendapatan digunakan untuk konsumsi tetapi sebagian juga untuk disimpan (saving).

Sertifikat Wadiah Bank Indonesia mempunyai hubungan yang positif dan signifikan terhadap Tabungan Mudharabah. Ini artinya ketika outstanding SWBI mengalami naik, maka Tabungan Mudharabah juga akan meningkat. Untuk mengatasi kelebihan liquiditas Bank Inbonesia menerbitkan SWBI. Sebagai bukti penitipan dana Bank Syariah, maka Bank Indonesia memberikan presentese bonus tertentu. Ketika bonus SWBI naik maka equivalent rate of return juga akan naik. Karena equivalent rate of return (bagi hasil) pada simpanan mudharabah naik maka Tabungan Mudharabah juga naik.

Penelitian yang dilakukan memiliki keterbatasan diantaranya periode pengamatan dan kemungkinan masih terdapat variabel lain yang mempengaruhi jumlah Tabungan Mudharabah. Oleh karena itu, hasil penelitian ini belum dapat mengungkap lebih jauh pengaruh terhadap Tabungan Mudharabah. Atas kelemahan atau keterbatasan penelitian ini, maka beberapa saran untuk penelitian mendatang yaitu dengan menggunakan variabel Jumlah jaringan kantor Bank Syariah dengan menambahkan periode waktu pengamatan, dan juga menambah variabel bebas (makro) lainnya seperti Jumlah Uang yang beredar dan Kurs yang kemungkinan mempengaruhi Tabungan Mudharabah.

\section{PUSTAKA ACUAN}

Arifin, Zainul. 2005. Dasar-dasar Manajemen Perbankan Syariah. Jakarta: Pustaka Alvabet.

Ascarya. 2007. Akad dan Produk Bank Syariah. Ed. 1, Cet. 1, Jakarta: RajaGrafindo Persada.

Banowo, Emilianshah dan Budi Hermana. 2010. Hubungan Equivalent Rate Simpanan Mudharabah dengan Sertifikat Wadiah Bank Indonesia. jurnal diakses tanggal 23 April 2010, dari http://proceeding.seminar nasional.pdf

Donna, Duddy Roemara dan Dumairy. 2010. Variabel-Variabel yang Mempengaruhi Permintaan dan Penawaran Mudharabah Pada Perbankan Syariah di Indonesia. jurnal diakses tanggal 26 Juni 2010, dari http://sosiosain.permintaan-penawaran-mudharabah,html. 
Chapra, M. Umer. 2000. Islam dan Pembangunan Ekonomi, Jakarta: Gema Insani Press.

Ghafur W, Muhammad. 2007. Protet Perbankan Syariah Di Indonesia Terkini (Kajian Kritis Perkembangan Perbankan Syariah). Yogyakarta: Biruni Press.

Hamid, Abdul. 2009. Pasar Modal Syariah, Jakarta: Lembaga Penelitian UIN Jakarta.

Karim, Adiwarman A. 2004. Akad dan Produk Perbankan Syariah, Jakarta: PT. RadjaGrafindo Persada.

Khalwaty, Tajul. 2000. Inflasi dan Solusinya, Jakarta: PT. Gramedia Pustaka Utama.

Kuncoro, Mudrajad. 2003. Metode Riset untuk Bisnis dan Ekonomi, Jakarta: Erlangga.

N. Gujarati, Damodar. 2007. Dasar-Dasar Ekonometrika Jilid 1dan 2, Jakarta: Erlangga.

Mankiw,N. Gregory. 2002. Principles of Economics: Pengantar Ekonomi Makro, Jakarta: Erlangga.

Mankiw,N. Gregory 2003. Teori Makroekonomi. Ed. 5, Jakarta: Erlangga.

Mochtar, Firman. 2006. Hubungan Perilaku Simpanan Masyarakat di Perbankan dan Pertumbuhan Ekonomi, Jakarta: Jurnal Ekonomi Pembangunan Indonesia.

Rejekining, Tri Wahyu dan Banatul Hayati. 2004. Analisis Faktor-Faktor Yang Mempengaruhi Tabungan Daerah Di Kota Semarang. Jurnal Dinamika Pembangunan Vol. 1 No. 1/Juli 2004 diakses tanggal 17 Nopember 2010, dari http://www.dinamikapembangunan.co.id.pendapatantabungan.html.

Setyarini, Ekaning dan Budi Hermana. 2004. Perbandingan Equivalent Rate Simpanan Mudharabah dengan Suku Bunga Deposito Bank Indonesia Pada Periode Januari 2002 Oktober 2004. Jurnal diakses tanggal 23 April 2010, dari http://proceeding.seminar nasional.pdf

Sukirno, Sadono. 2004. Teori Pengantar Makro Ekonomi, Jakarta: PT. Raja Grafindo Persada.

Sudarsono, Heri. 2002. Konsep Ekonomi Islam, Jogyakarta: Ekonisia.

Syafi'i Antonio, Muhammad. 2001. Bank Syariah: dari teori ke praktek, Ed. 1, Yogyakarta: UGM Press.

Teguh Wiyono dkk. 2005. Prospek Bank Syariah Pasca Fatwa MUI, Yogyakarta: Suara Muhammadiyah. 
Wibiwo, Aldrin dan Susi Suhendra. 2004. Analisis Pengaruh Nilai Kurs, Tingkat Inflasi, dan Tingkat Suku Bunga terhadap Dana Pihak Ketiga Pada Bank Devisa di Indonesia," Jurnal diakses tanggal 21 Agustus 2010, dari http://repository.usu.ac.id/bitstream/123456789/14030/09E00329.pdf

Winarno, Wing Wahyu. 2007. Analisis Ekonometrika dan Statistik dengan E-Views, Yogyakarta: UUP STIM YKPN.

Wiroso. 2005. Penghimpunan Dana dan Distribusi Usaha Bank Syariah, Jakarta: Grasindo. 